\title{
From employee representation to problem-solving: Mainstreaming OHS management
}

\author{
Hasle, Peter; Seim, Rikke; Refslund, Bjarke
}

Published in:

Economic and Industrial Democracy

Link to article, DOI:

$10.1177 / 0143831 \times 16653187$

Publication date:

2019

Document Version

Early version, also known as pre-print

Link back to DTU Orbit

Citation (APA):

Hasle, P., Seim, R., \& Refslund, B. (2019). From employee representation to problem-solving: Mainstreaming OHS management. Economic and Industrial Democracy, 40(3). https://doi.org/10.1177/0143831X16653187

\section{General rights}

Copyright and moral rights for the publications made accessible in the public portal are retained by the authors and/or other copyright owners and it is a condition of accessing publications that users recognise and abide by the legal requirements associated with these rights.

- Users may download and print one copy of any publication from the public portal for the purpose of private study or research.

- You may not further distribute the material or use it for any profit-making activity or commercial gain

- You may freely distribute the URL identifying the publication in the public portal

If you believe that this document breaches copyright please contact us providing details, and we will remove access to the work immediately and investigate your claim. 


\title{
From employee representation to problem-solving: Mainstreaming OHS management
}

\section{Peter Hasle}

Aalborg University Copenhagen, Denmark

\section{Rikke Seim}

Technical University of Denmark, Denmark

\section{Bjarke Refslund}

Aalborg University Copenhagen, Denmark

\begin{abstract}
The role of occupational health and safety representatives is changing. A study in 60 Danish enterprises indicates that representation, and especially negotiation on behalf of colleagues, has diminished. The work environment is mainstreamed in many enterprises and is rarely an area of conflict. The role of OHS representatives has accordingly changed to focus on solving specific problems in the workplace as an integrated part of daily operations. Both management and colleagues consider the OHS representatives as a resource that can be utilized to manage the work environment. The consequences of this development for the employees may be a stronger joint management-employee effort to improve the work environment, but also management domination and an accordingly weaker employee voice in some companies.
\end{abstract}

\section{Keywords}

Employee voice, mainstreaming, occupational health and safety management, regulation, safety representatives

\section{Corresponding author:}

Peter Hasle,

Centre for Industrial Production,

Aalborg University Copenhagen,

A.C. Meyers Vænge 15,

2450 Copenhagen SV, Denmark.

Email: hasle@business.aau.dk 


\section{Introduction}

The right of the employees to elect occupational health and safety representatives (OHS representatives) evolved in most Western European countries in the decades after the Second World War. Initially, the push for OHS representatives came in many countries from the labour unions as a supplement to the shop stewards and the right to elect OHS representatives is often based on collective agreements. During the time of work environment reform and new legislation, which took off in the 1970s, the right to elect OHS representatives was included in many European laws (James and Walters, 2002; Walters and Frick, 2000). Subsequently, from 1989 the EU framework directive required provisions for OHS representatives in all the EU countries, including in the countries that had not had OHS representatives before (Walters, 2002; Walters and Nichols, 2009). Having its point of departure in the union movement, the main function of the OHS representatives was to ensure the interest and voice of the employees in the effort to secure a healthy and safe work environment. The OHS representatives should therefore give voice to the employees on these matters. The unions had pushed for the right to information and involvement in issues which could have health and safety consequences for the employees, and also demanded protection against dismissal of $\mathrm{OHS}$ representatives. These rights have, to a varying degree, been regulated in collective agreements and legislation. The extent to which these rights have been successfully achieved and whether these rights have resulted in a healthier and safer work environment has been discussed in the literature and the overall conclusion is that, in many cases, the rights are rather fragmented and insufficiently secured in order for the OHS representatives to work effectively, yet in cases where they do, there is a trend towards a better work environment (Walters, 1995; Walters and Nichols, 2009).

The OHS legislation has changed towards more reflexive regulation during the last decades. It started with the Robens Report (1972) from the UK, followed by reforms of the legislation in the Nordic countries in the 1970s and subsequently implemented in most of the European Union after the EU OHS framework directive in 1989 (Walters, 2002). An important element in this type of legislation is a higher level of self-regulation, where the full responsibility for a safe and healthy work environment is placed more explicitly on the employers (Aalders and Wilthagen, 1997; Wilthagen, 1994). Employee participation was considered to play an important role and workers and OHS representatives became increasingly integrated in the legislation. The role of the $\mathrm{OHS}$ representatives also changed, as the representation provided by the legislation also implied that the OHS representatives' role was not only to secure the interest of the employees but also to participate in the implementation of this more reflexive legislation. It may create a development where OHS representatives as employee-elected representatives move closer to a management position as they get involved in problem-solving, which has been problematized in the literature (see for instance Rasmussen et al., 2014; Sjöström, 2013).

In conjunction with the development of the regulation of OHS representatives, the employer understanding of, and priority given to, the work environment has also developed, to, among other aspects, focus much more on OHS management (European Agency for Safety and Health at Work, 2010; Frick et al., 2000; Hasle and Zwetsloot, 2011). The work environment is more commonly considered an issue which should be managed in the same way as other managed issues in enterprises (Dyreborg, 2011; Frick, 2011). Even though the extent can be discussed, there is also a growing awareness that good OHS management can lead to improved working conditions (Robson et al., 2007) and also to improved productivity (see an example of one of several reviews in Neumann and Dul, 2010). 
Over the years, the role of OHS representatives has most frequently been analysed in the literature from an interest perspective (see e.g. Walters and Nichols, 2007). While this perspective is still relevant, it can also be expected that the involvement of OHS representatives in problem-solving as well as the development of both employer and employee attitudes have changed the role of OHS representatives thereby requiring an adjustment in our analytical perspective. This, however, has so far achieved limited research attention. The main research question in this article is whether OHS representatives still play the role of democratic voice and caretaker of employees' interests, or if more fundamental changes have occurred and altered the role of OHS representatives. The article presents a novel insight into how the workplace practice of OHS representatives is affected and shaped by the organizational context. As society changes so does the regulation and context of OHS - and therefore the role of the OHS representative (Dyreborg, 2011; Walters and Nichols, 2009). We show - based on empirical evidence from Denmark - how the work environment tends to be mainstreamed in companies. This has led to the identification of a number of different typologies of roles, where the common denominator is the integration of OHS management into enterprise operations, and limited attention paid to traditional interests.

The article is based on an empirical investigation of 60 case companies, which have been visited and interviewed regarding the organization of their OHS management. Building on data from this study and on insights from the literature, we suggest a typology of five important roles of OHS representatives, which can be found in different combinations in workplace practice. These typologies also reflect more general developments found in labour market organization and functions, where there has been a tendency for employee representatives to move from pure interest representation towards a more collaborative approach (Kristensen and Rocha, 2012), but also a decline in the influence of organized labour in most countries (Baccaro and Howell, 2011), which in turn can affect OHS representatives' interaction with workers (Ollé-Espluga et al., 2014).

\section{Background}

The existing literature on the roles of OHS representatives consists of both quantitative and qualitative studies. The quantitative studies typically aim at mapping the density of OHS representatives and the activities they undertake at their workplaces (see e.g. Walters et al., 2012). In spite of the legislation, there are still problems in many countries in securing a sufficiently high coverage of elected OHS representatives (Walters et al., 2012). However, it is difficult to use the quantitative studies to understand how the OHS representatives' role is performed in daily practice. Moreover, other studies have found that OHS representatives give priority to advising employees about safety rules and encouraging them to report injuries, and, in addition, that they often experience too few resources (time and access to knowledge) as well as too little involvement in important decisions regarding the work environment (Blewett and Dorrian, 2011; Frick, 2013; García et al., 2007; Sjöström, 2013; Tasiran et al., 2005). Qualitative research on the role of OHS representatives has the potential to include among others the context and to study the perspectives of different stakeholders, and a number of interesting qualitative studies dealing with the role of OHS representatives have been published over the last few years (e.g. Frick, 2013; Hall et al., 2006; Harris et al., 2012; Hovden et al., 2008; Rasmussen et al., 2014; Sjöström, 2013; Walters and Nichols, $2007,2009)$. Here we emphasize three of these studies since they also deal with some kind of typology of the OHS representatives' role, although they arrive at different types than us.

Hall et al. (2006) conducted a study of Canadian industries manufacturing auto parts and showed that OHS representatives mainly utilized two overall strategies. One group followed a technical-legal strategy with a focus on legislative requirements and another followed a more politically active 
strategy (and thus more often contesting management) (see also Ollé-Espluga et al., 2014: 348). In the politically active group there were two sub-groups, of which the most successful sub-group focused on what the authors call knowledge activism, where they utilize knowledge from both colleagues and outside to pressure for improvements in the work environment. This binary distinction was also found in a Spanish study, however with a tendency towards technical approaches among the OHS representatives, partly explained by the declining impact of organized labour (Ollé-Espluga et al., 2014). While these results are from a European context, they may not be transferable to the Danish context, which still remains highly organized, especially compared to Spain. In another study, Harris et al. (2012) identified four role types for OHS representatives: administrators, inspectors, problem solvers and craft experts. These studies are mainly based on the specific approach or role taken by the individual OHS representative. It is less clear in these studies how the organizational context shapes their role. The expectations from colleagues and management, as well as OHS regulation and the OHS management system, define the frames for the $\mathrm{OHS}$ representative function and thereby strongly shape the OHS representatives' role.

OHS management and regulation with a high degree of employee involvement are generally found to be more efficient in improving the work environment (Gallagher et al., 2001; Knudsen et al., 2011; Walters, 2002; Walters and Nichols, 2007). However, employee involvement is not necessarily simple or straightforward (Sjöström, 2013). In some cases the OHS representatives may experience a conflict of interest related to, for instance, risk assessment - where the colleagues have one experience and the employer and OHS professional have a quite different understanding. That can particularly be the case in the discussion of control measures. Another potential conflict could be between the wish to secure the numbers of jobs and getting rid of the most dangerous jobs by for example automation. It can therefore be an ambiguous question about how to handle the interests of the employees, especially regarding the strategy towards the employers. Do the OHS representatives experience employers as being against the interests of employees regarding the work environment, thereby calling for a conflict-oriented strategy, or do they experience a positive employer attitude which calls for a more collaborative strategy? Therefore, securing the interests of the employees has never been a straightforward case for the OHS representatives, with studies showing conflicting role expectations between legislation, employers, employees and the representatives themselves (Hovden et al., 2008; Rasmussen et al., 2014; Sjöström, 2013).

It has been common in Denmark and to a lesser degree in the other Nordic countries to use the 'sidecar' metaphor to describe firms' health and safety efforts, implying a marginalization of OHS issues from the general management of production, in such a way that OHS was exclusively handled by the OHS representatives and OHS committees (Aminoff and Lindström, 1981; Cutler and James, 1997; Frick, 1990; Jensen, 2002a). The sidecar metaphor is consistent with the representative and conflict-oriented OHS representative role, as the experience of not having influence and management's neglect of OHS (hence the sidecar) tend to trigger resistance and a strong voice. However, several scholars have suggested that there has been a movement from more distributive and conflict-based negotiations within firms towards more integrated and consensually based negotiations, particularly in the Nordic countries (Kristensen, 2003, 2011; Kristensen and Rocha, 2012). In line with these tendencies, Danish shop stewards are increasingly seeing themselves as problem solvers rather than negotiators (Navrbjerg and Larsen, 2015), and the question is whether this tendency can also be found in OHS issues.

The potential sidecar problem has been addressed by regulatory and political changes calling for more reflexive and integrative approaches to the work environment. Such is the case with the introduction of the EC/1989/391 framework directive and, for example, Sweden and Norway, which 
developed their own legal requirement for internal control systems (Walters and Jensen, 2000: 98). The question whether this reflexive turn has led to improvements in the work environment has been investigated in many studies (see e.g. Frick and Johanson, 2013; Jensen, 2002b), or alternatively whether it has simply resulted in deregulation of OHS as claimed by critics (Busck, 2014; Frick et al., 2000). So far the evidence that the legislative and regulatory changes have led to actual changes in firms' behaviour has been modest (see Frick and Johanson, 2013 for a discussion). It is far from certain that a mere change of legislation will cause substantial changes in the way firms behave. In this article we study whether firms' attention to the work environment has changed and in particular whether the roles of OHS representatives have changed.

We propose to use the term 'mainstreaming' of the work environment in order to describe important changes in the employers' approach to this area. The concept of mainstreaming originates from the field of gender equity, and in particular the policy domain - where it was widely promoted by the European Union as a descriptor of the move from treatment of gender issues as separate and isolated issues to integration of gender into the main management decisions (Booth and Bennett, 2002). The concept is also used in this way by the $\mathrm{EU}$ in order to increase the integration of OHS and management (European Agency for Safety and Health at Work, 2010). We find the concept useful as an obverse to the sidecar concept of $\mathrm{OHS}$, and we argue that it describes a different process than the mere implementation of reflexive regulation. We apply mainstreaming in our analysis where one key finding is that employers increasingly include OHS in the operational management of the workplace based on management logic and not regulatory logic. Nonetheless, mainstreaming has also been criticized and disputed by gender scholars for moving the attention away from the real issue of gender equity and subsuming it under other policy areas (Walby, 2005), which perhaps could also be a relevant critique for the use of the concept in the OHS field.

\section{The Danish context}

The role of the unions has followed very different trajectories across European countries. In most countries the right to establish unions and the fight to secure legitimacy have been on the agenda for the last century and even nowadays seem to be retracting in many European countries (Gumbrell-McCormick and Hyman, 2013). However, the Scandinavian countries have been marked by an early recognition of the unions and a high membership (Andersen et al., 2014; Crouch, 2012; Hasle and Sørensen, 2013), with union density remaining comparatively very high at around $68 \%$ in Denmark (DA, 2014: 187), although declining a little over the last decades. Although the unions' power may have shrunk some, Danish unions still have a very strong power base with wide workplace coverage (Andersen et al., 2014). The Danish labour market is characterized by being mainly regulated through voluntary collective agreements between the social partners, and there is no legislation on minimum wages or legal extension of collective agreement (Andersen et al., 2014). Around $84 \%$ of all Danish employees are covered by a collective agreement (DA, 2014). While the political system does not interfere in wage negotiation and most working conditions issues, there are framework legislations on several issues including working hours and the internal organization of OHS activities. In this sense OHS issues have been somewhat trapped between the role of the voluntary regulation tradition and the role of legislation, where the unions to some extent have not given the work environment the necessary priority in order to improve it, but have at least in some cases prioritized wages and jobs (Busck, 2014).

Unions and employers have, especially in the face of the long post-Second World War economic boom, developed a more collaborative and trust-based approach in the Nordic countries which has influenced the field of work organization as well as the work environment (Elden, 1986; Gustavsen, 2007; Jørgensen, 2002). Among other factors, this has led to a more teamwork-based and egalitarian 
work organization (Lorenz and Lundvall, 2011), stronger local cooperation between employers and workers (Hagen and Trygstad, 2009) and a greater influence over work tasks (Gallie, 2009). Unions are also heavily involved in workplace cooperation aimed at improving work outcomes and thus making Danish firms competitive (Kristensen, 2003; Kristensen and Rocha, 2012). The consensual Nordic approach is also reflected in the OHS system, especially in Denmark and Sweden (Frick, 2013: 52 ), and only $8 \%$ of Danish OHS representatives feel they have a less than good, or even bad, relationship with management (Navrbjerg et al., 2010: 48) and a 2006 survey in Sweden showed that only 5\% of Swedish OHS representatives felt that management opposed them (Frick, 2013: 63).

Using Denmark as an example, the fundamental right to elect OHS representatives was secured with the Work Environment Act of 1975. An important emphasis of the legislation was on securing rights for OHS representatives to be informed and involved in the control of the work environment. The specific Danish method was to establish a collaborative system consisting of OHS groups (representatives and first line managers) at the local departmental level and joint OHS committees at enterprise level. This internal so-called 'OHS organization' with election of OHS representatives and establishment of OHS groups and committees was implemented in most Danish private and public enterprises with more than 10 employees (Sørensen et al., 2009) and in $201082 \%$ of all employees had an OHS representative at their workplace, compared with $52 \%$ that had a shop steward (Navrbjerg et al., 2010: 25). The wide coverage was achieved through, among other elements, enforcement by the authorities and positive support from the social partners.

In the first decades after the Work Environment Act was passed by parliament, the representative part of the role - including negotiating on behalf of colleagues - dominated (Rieper, 1985). However, as time passed, the role of OHS representatives has changed significantly. An important precursor for the new role has been a series of successive changes of the legislative requirements for the establishment of the OHS organization. The original design was based on the understanding of an organization as something resembling a medium-sized industrial plant with a couple of hundred employees. As organizations became more complicated, and as the public sector also established $\mathrm{OHS}$ organizations and elected $\mathrm{OHS}$ representatives, the standard system became a straitjacket, and the Danish Working Environment Authority started to give dispensation for alternative setups though always with elected OHS representatives as an integral part (Hasle, 2001). This development was subsequently mirrored by changes in legislation which among other things allowed the social partners to make local agreements about alternative ways of running the OHS organization (Sørensen et al., 2009). The most significant change came in 2010, with a more fundamental reform of the requirements for an OHS organization. The legislation still requires the establishment of a basic OHS organization, but it is now much more flexible and it is up to the individual enterprises to design a system suited to the context of their particular firm. It is still required to have elected OHS representatives but otherwise there are very few demands for specific organizational forms although there are still requirements for certain activities such as the training of $\mathrm{OHS}$ representatives and first line managers, and yearly deliberations between the management and employees to evaluate the preceding year and plan for the next.

Despite changes in the industry structure with declining employment in manufacturing, where $\mathrm{OHS}$ representation traditionally had a strong impact due to imminent risks in that sector, Danish workplaces still have a very high density of OHS representatives and due to the OHS legislation almost all workplaces with more than 10 employees have an elected OHS representative. The majority of OHS representatives do not generally see themselves as union representatives and they understand the OHS representative role as being clearly separate from union activity, as do 
management in general. However, some of the OHS representatives see their activities as a joint role with the shop steward (Navrbjerg et al., 2010: 17); we will further discuss this role below.

\section{Methods}

This article reports from a study that investigated trends in the development of OHS management systems in Danish enterprises, with a special focus on the formal OHS organization including the OHS representatives. It was carried out in 2013-2014, three years after the new flexible Danish legislation had been implemented, in 2010. It is designed as an exploratory, multiple qualitative case study (Yin, 2009). Sixty workplaces were selected from a national survey of OHS activities in workplaces ${ }^{(1)}$ stratified by their extent of OHS activities. Cases were selected from workplaces with high and low activities respectively, in order to secure as much contrast as possible. Of the enterprises contacted $54 \%$ declined to participate in the research project. Refusal to participate was highest in the construction industry at $68 \%$, and lowest in the healthcare sector, where only $29 \%$ refused to participate. Moreover, as might be expected, the greatest refusal rate was found among enterprises with a low level of OHS activity, where $72 \%$ of the enterprises declined to participate. The cases were also stratified across five main labour market sectors - construction, manufacturing, private service provision, knowledge industry and healthcare. In so doing, the most important sectors in society were represented. Twelve cases from each sector were included in the study. Workplaces were defined as the local physical unit, which could cover an independent firm as well as a workplace affiliated to a larger private firm or a public organization such as a municipality.

Key personnel related to each organization's OHS management were interviewed. Between two and six people were interviewed in each enterprise, with the key interviews being with OHS representatives and OHS managers. In addition, employees, line managers and shop stewards were interviewed, depending on the context and the availability of the relevant staff. OHS representatives and OHS managers were interviewed separately. However, in some cases the parties insisted on joint interviews as they claimed that they shared opinions and experience and separate interviews would give a flawed picture of the workplace practice. In addition, walk-throughs were conducted at most of the workplaces. These included spot interviews with employees and scrutinizing issues touched upon during interviews.

The interview guide was designed in order to cover the whole set of activities carried out by the OHS organization, which, in the Danish context, includes OHS representatives, management representatives, and in most cases an OHS coordinator/manager. The interview guide included the following themes: internal and external context, collaboration and activities of the OHS organization and the different stakeholders, development in the work environment over the last few years, the most important risks and how they are addressed, assessment of the effects of OHS activities, changes in the OHS organization over the last few years, competence development, planning of activities, and the integration of the work environment with operation and strategy. This approach allowed us to study the actual role played by the OHS representatives as their involvement in the various activities of the OHS organization was clearly identified.

The workplaces were visited by an experienced researcher. Extensive notes were taken during the visit and gathered in a standardized case study report in order to secure comparability. Following this, the reports were analysed for common trends by thematic coding and in conjunction at a coding seminar with the participation of all researchers involved. As part of our qualitative research strategy we identified common themes or 'types' in the data (Kluge, 2000). Based on this systematic analysis of the data gathered in the 60 cases, we arrived at the typology presented below, where we 
identified five different OHS representative roles which are related to how OHS management is generally practised in the companies.

\section{Results}

The results of the multiple case study indicate a significant shift in the role of OHS representatives. The more traditional role of OHS representatives as an employee representative acting as a spokesperson on work environment issues in line with the role of shop steward was only observable in few of the cases, and the interviewed OHS representatives did not in general identify themselves with such a role. They appreciate being included in problem-solving, and they did not yearn for a more interest- and possibly conflict-oriented role. This OHS position is in accordance with another important finding: a clear trend towards mainstreaming of the work environment in the enterprises. This has become one issue among many involving certain tasks and the allocation of staff.

Mainstreaming in the workplaces studied can be characterized by four key observations:

- Management does not consider the work environment as an issue which needs to be given priority due to employee demands, but as an issue which is part of regular operations.

- Systems are established which are expected to handle work environment issues on a day-to-day basis and to ensure that major problems in terms of accidents, illness, employee complaints and enforcement notices from inspectors are avoided.

- The work environment is treated in the same manner as other specific issues such as quality management, environmental management and HR management.

- Staff and resources are allocated to carry out the tasks in the OHS organization, and OHS representatives are considered part of this staff.

However, the mainstreaming of the work environment does not necessarily imply that a high health and safety level is given priority and is particularly secured in practice. It merely indicates that the work environment is not a conflict issue and that a purely ad hoc approach results in too many problems.

The setup and function of the OHS organization as well as the roles of the OHS representatives are very specific for each workplace visited. Each of them has their specific context, history and conditions, which make each workplace and $\mathrm{OHS}$ organization unique.

From the data from the 60 cases studied, we have identified five ideal types of the role of the OHS representatives which are based on the style of OHS management, and can be used to highlight important elements of the OHS representatives' roles, even though each individual workplace may contain elements of several typologies. The typologies were identified during the thematic coding of the entire data set, with a focus on trends regarding the role of OHS representatives and the general management of OHS in the cases. The five ideal types are:

1. Professional OHS representatives.

2. Systems maintenance OHS representatives.

3. OHS representatives integrated in core tasks.

4. Political OHS representatives.

5. OHS representatives in a management-driven system.

In the following, we define the characteristics of these five ideal types and present for each one a case which is dominated by the specific typology. 


\section{Professional OHS representatives}

In some cases, we see a tendency towards fewer OHS representatives, with more resources allocated and extended responsibility. This condensation of the role of OHS representative can be regarded as a professionalization of the role. In some cases the professionalization of OHS representatives is primarily built on the experience gathered through daily OHS work and spending the majority of the working hours on OHS activities. However, other case companies work in a more structured manner, with further developing competencies including ongoing training and education.

This ideal type is present as a dominant trend in about $20 \%$ of the cases. In two of the 60 cases, the OHS representative worked full-time in this role, which is also reported to be quite common in Sweden where around $8 \%$ of OHS representatives in 1996 were either full- or half-time representatives and this does not appear to have changed a lot since (Frick, 2013: 61-62). In both of these cases the OHS representative was the only employee working in OHS, and they were both closely associated with management. The job description of these OHS representatives was similar to the job description of an OHS officer with a professional degree. The professional OHS representative is a particularly dominant trend in the manufacturing industry, but the trend of concentrating the OHS representative role towards fewer employees is also seen in both healthcare and construction.

The role of the professional OHS representative is particularly exemplified in the case of a small food plant, which employs a permanent workforce of approximately 35 unskilled workers and double that during the peak season. It is owned by a larger corporation. By 2011 the company had started to feel the economic crisis with declining sales. Almost simultaneously labour inspectors visited the company and issued several enforcement notices. This situation was used to reorganize the plant. A new management was appointed, who decided to let the OHS representative (who was also elected as shop steward) take full-time responsibility for OHS management. The OHS representative now handles all daily tasks associated with the work environment. Furthermore, he works closely with the plant manager on managerial tasks such as production planning, quality control and implementation of new technology. This has resulted in a substantial improvement in the work environment. The employees expressed satisfaction with the OHS representative's handling of the work environment and regard the close cooperation with management as an advantage in solving daily health and safety problems. Nevertheless, at the same time, several employees expressed incipient wariness of the OHS rep; they had doubts about whether his loyalty lay with management or employees in cases of disagreement and conflict (as also discussed for a Swedish paper mill in Sjöström, 2013: 239).

\section{Systems maintenance OHS representatives}

In contrast to the professionalization of the OHS representative some cases had developed a role for OHS representatives with a focus on systems maintenance, which is often seen in larger enterprises with high levels of systematizing and standardization of OHS activities. These enterprises have most often employed full-time OHS officers with a professional degree. Here the OHS representatives' main function is to support the OHS officer in the issues of systems maintenance, follow-up on procedures and other OHS activities that are directly linked with the daily, operational OHS management on the shop floor, and does not necessarily emphasize contact with colleagues. The OHS representatives are formally allocated time for the task, normally one or two days per week. Therefore, there is less scope for the OHS representatives to individually define their role.

This ideal type is seen in approximately $35 \%$ of the enterprises. This particular type is often seen in larger enterprises in both the public and the private sector. Some of these enterprises have certified 
OHS management systems, which require a great deal of maintenance, and some of these administrative tasks fall upon the employee-elected OHS representatives.

One example of systems maintenance by OHS representatives is seen in a case from the service sector. This company is a larger enterprise providing facility services and damage control and has approximately 400 employees. The company's environmental manager is in charge of the OHS management, and he has designed an OHS management system based on several detailed procedures and checklists. The OHS representatives are responsible for the daily operations of the OHS management system and they report to the environmental manager. Consequently, there is little room for personal initiative for the OHS reps and the representative part of the role is replaced by a more administrative role. The OHS organization has, in this case, been transformed into a management hierarchy, where the environmental manager is in charge and the OHS representatives execute the daily OHS operations.

\section{OHS representatives integrated in core tasks}

In some cases $\mathrm{OHS}$ activities are handled as an integral part of the core task of the organization, and OHS considerations are not addressed as specifically concerning the health and safety of employees. The rationale behind improvements and initiatives are linked to the enterprises' operation of the core tasks. Often OHS representatives work closely together with management and shop stewards about solving day-to-day operational problems as well the longer term development of the workplaces without specifically highlighting the activities as OHS related. The staff involvement is often high as activities important to OHS are part of their daily work.

This ideal type is seen in approximately one third of the cases. It is particularly noticeable in cases from the healthcare and social service sector. One likely reason is that in this sector, the main work environment problems are the psychosocial factors and musculoskeletal strain closely related to the core activities, for instance in elderly care, child daycare and primary schools.

One example is an elderly care centre in a medium-sized municipality. The centre has 40 employees and most of the elderly residents suffer from dementia. It has one OHS representative who works closely with the shop steward and the centre leader. The OHS representative describes the three as a team where they coordinate activities and, for instance, jointly prepare staff meetings. The work environment activities are focused on the relationships with the elderly residents and their relatives. The provision of high-quality care to the elderly residents and taking care of the work environment are considered to be completely integrated. Among the most important issues have been coordination across shifts, social support in difficult situations and treatment of challenging residents in order to avoid harassment and violence. The OHS representative explains that the staff inform her about problems, which she then raises with the manager and the shop steward. However, in some cases staff also go to one of the two other persons and they subsequently share the issues, discuss solutions and put them on the agenda for staff meetings.

\section{Political OHS representatives}

It is possible in a few cases to identify important elements of the traditional spokesperson role. However, the modern political OHS representative is not solely the voice of the employees in securing a sound work environment. The modern political OHS representatives both act and regard themselves as politicizing actors within the organization (cf. Hall et al., 2006). In line with the concept of 'political reflexive coordinator' introduced by Broberg and Hermund (2004), the political $\mathrm{OHS}$ representatives possess organizational understanding and are able to analyse their own organization in order to identify converging and conflicting interests. Through this, they thereby secure political support from both management and employees for their own personal OHS agenda. 
Elements of the political OHS representative can be identified in seven of the 60 cases. This ideal type is represented in all five sectors.

One example of a political OHS representative is in a public construction and road maintenance enterprise with 70 employees. There are two OHS representatives in the company. However, their approaches to the role are very different. While one of the OHS representatives has a more traditional role with employee representation and operational OHS activities, the other OHS representative in this enterprise has an approach in line with the 'political reflexive coordinator'. He is very active and influential on all managerial levels in spite of having no formal power. Moreover, the representative is very conscious of the need to safeguard both the employees' and management's interests while implementing his own personal agenda regarding OHS. The OHS manager in the company has a similar approach, and she has been able to closely position herself to the firm's management so that all major decisions are made jointly between the management and the OHS manager. It is the expressed strategy of both the OHS manager and the 'political' OHS representative to utilize this political approach to OHS management internally in the company.

\section{OHS representatives in a management-driven system}

In several of the cases management plays the dominant role in OHS. All strategic OHS activities are centralized at the top level of the enterprise, most of the daily operational OHS activities have been standardized, and the overall responsibility for the daily operation of the work environment is with professional OHS officers or placed with the first line managers. As a result, the OHS representatives are more or less pushed to the side-lines, and the employee-elected OHS organization is left as an empty shell with no real function or power.

Elements of management-driven OHS activities are seen in approximately $25 \%$ of the cases. This can most often be observed in larger enterprises, although some smaller and medium-sized enterprises also carry elements of management domination, but in these cases it is more in the form of lack of priority and ad hoc oriented activities.

One extreme example of domination by management is from a larger financial enterprise with over 4000 employees. Top management had assessed the traditional set-up of the OHS organization as non-functioning; neither the OHS representatives nor the management were adequately committed. In order to increase priority, the senior management decided to integrate the work environment into operations. The line management has therefore been given full responsibility for OHS management. All managers are required to follow a basic web-based OHS training programme. The first line managers are supported by a small unit of professional OHS officers. The number of OHS representatives was subsequently reduced considerably, and they now cover large geographical areas with up to 15 separate locations each, with which they do not have any natural physical contact. The few remaining OHS representatives get access to information and seminars, but they do not play a clear role in the OHS activities, and it seems to be difficult to gain access to work environment decisions as not all line managers follow up on the new responsibility in the way it was intended.

\section{A mixture of typologies}

In the above five typologies we have indicated the approximate share of workplaces which were dominated by a specific typology. However, some workplaces have strong trends from more than one typology and the percentage of typologies indicated therefore adds up to more than the 60 participating workplaces. Moreover there are even a few enterprises ( 3 cases; $5 \%$ ) dominated by an ad hoc approach where none of the typologies is dominant. 


\section{Discussion}

Several interesting observations can be highlighted from the study. It was remarkable that we found a clear trend towards mainstreaming of the OHS organization in most of the workplaces.

Transferring the concept from gender research is useful to capture the movement of the work environment from a sidecar function into the daily operations in most of the workplaces analysed.

Nonetheless, we have still identified two alternative approaches to the mainstreaming tendency: a continuation of the 'sidecar' approach and an ad hoc approach. The sidecar approach is dominant in workplaces where the OHS work is still characterized by having the formal status required by law but without any genuine or efficient integration into the daily operations of the firms. This approach is mainly found in smaller and mediumsized workplaces which are known to give lower priority to work environment (Sørensen et al., 2007). The ad hoc approach is characterized by the absence of a systematic approach to OHS as well as overall guiding policies on OHS. The workplaces with an ad hoc approach only undertake activities when they are forced to do so in one way or the other, such as receiving improvement notifications from the labour inspectors or the occurrence of accidents.

Again is it important to emphasize that both these approaches and the OHS representatives' typologies are ideal types and thus tend to occur in various combinations and to varying degrees in the cases and they can obviously change over time. In this study we found that the traditional 'sidecar' role of OHS (Aminoff and Lindström, 1981; Frick, 1990) was mainly present in workplaces where the Systems maintenance typology dominated, but there were also elements of the sidecar approach in conjunction with the Political and Management-driven OHS representative typologies. However, the Systems maintenance typology also has associations with the mainstreaming tendencies as management expect the experts to take care of all operational issues before they become problems. The mainstreaming of OHS activities and organization is most closely associated with the Professionalization, Integration and Management-driven typologies, though there were trends of mainstreaming in almost all the cases.

The consequence of mainstreaming the work environment is that it is increasingly seen and treated as any other issue in the enterprise. As with other operational issues, management search for OHS systems that contribute to a cost-efficient operation and safeguard against problems which could disturb the core business. The management want to show the enterprise as an efficient and attractive, highly ethical organization, and problems with the work environment do not fit into such a picture. It wants a system which protects against poor publicity, criticism from the authorities and disgruntled employees. It does not, however, per se secure a high level of work environment. As for other management issues, ambitions, competence or the economy may be a constraint for the level of priority given to the work environment.

In the majority of cases OHS representatives are included in the mainstreamed organizational solutions. Even though this mainstreaming does not secure a high-level work environment, we do not identify any general trends of downgrading the work environment or the exclusion of OHS representatives. This development seems to be well aligned with the viewpoint of some OHS representatives who appreciate being included in problem- solving (Hohnen and Hasle, 2010; Navrbjerg et al., 2010: 36; Rasmussen et al., 2014). The development is, in many cases, followed by a trend towards fewer and more professional OHS representatives, ones that are better educated and spend more time on the work environment activities. It is therefore possible that this more flexible system opens the way for a stronger OHS representative voice because the representatives become more qualified and are able to spend the necessary time to be involved. 
However, the change of focus from representation to problem-solving is not without potential drawbacks. There is a risk of contradictions for the OHS representatives, e.g. moving away from identification with their colleagues to identification with OHS professionals and/or management (Sjöström, 2013: 231-233), which has also been found in studies of shop stewards working closely together with management (Mathiesen and Hvenegaard, 2001; Rolfsen, 2011). Through doing so, they gain more insight into the understandings of management and they may therefore tend to accept their positions and move away from the position of their colleagues. In our study, this was particularly true in the case of the food plant, but it was also noticed in other cases. Therefore, there appears to be a need for a balance between a situation where too few OHS representatives spend all or most of their time on the representative function, moving them away from their colleagues, and where there are a sufficient number of OHS representatives with enough time and education which can be beneficial for both their colleagues and the enterprise.

In addition there are cases such as the financial enterprise where mainstreaming of the work environment and the quest for an efficient OHS management system tend to sideline OHS representatives, leaving them without any real influence (see also Dyreborg, 2011). However, in cases such as the financial enterprise the OHS representatives did not have a stronger influence prior to these changes, and their influence was therefore also limited under the old system. OHS management systems with a weak employee voice tend to be less effective (Frick, 2011; Walters and Nichols, 2007). A weak influence for the OHS representatives could probably also be the case in some of the more positive cases when it comes to more strategic decision-making. It was difficult in the case studies to gain any clear evidence in this respect, although the case of the food plant constitutes an example where the OHS representative did exercise an influence on more strategic decisions. However, many of the workplaces were affiliated to larger organizations, and both local management and OHS representatives have limited access to the strategic decision levels. These larger organizations normally have an OHS committee, where, in principle, the OHS representatives have the possibility to influence strategic decisions, though this has not been studied in this research project. Often, organizational decisions taken at a higher level in the firms or organizations, and outside of the influence of the local OHS rep, can have huge impact on the work environment at the workplace, e.g. reorganizing of workplaces and processes or changes in work and production practices. In some public institutions the fear of cutbacks affects the work environment very significantly.

This research has been carried out in Denmark, and the results are therefore particularly relevant to the Danish context. There is a clear risk that workplaces with a negative attitude towards OHS refused to participate, and the prevalence of mainstreaming may therefore be somewhat lower than indicated in the present study. It is therefore relevant to consider to what extent the results can be generalized to other countries, and in particular whether the trend towards mainstreaming of the work environment and the integration of OHS representatives into daily problem-solving can be identified in other countries. Traditions for a stronger top-down management and conflicts with unions may hamper such a development, but it is also likely that such trends can be found not only in Scandinavia but also in other countries. The goal of avoiding problems related to $\mathrm{OHS}$ as well as showing a high ethical profile will also exist in other national settings. However, only further research can provide answers to this question.

\section{Conclusion}

We conclude that there seems to be a simultaneous development in employer mainstreaming of the work environment and the introduction of a more flexible regulation of the organization of OHS 
management systems and the set-up for OHS representatives. This development opens up new possibilities for OHS reps - where they can play an important role in helping to improve the work environment for themselves and their colleagues. But the risk is, among others, that they may move away from identification with their colleagues. It must also be noted that the existence of legislation requiring the election of $\mathrm{OHS}$ representatives and an employee voice is an important prerequisite. If not, it could be expected that many enterprises will choose another strategy with a fully professional OHS management system and a rather low level of employee voice, as is seen in some of the workplaces studied.

The results also call for more in-depth studies of the actual function of the OHS management systems and the role of the OHS representatives. Potentially interesting questions may for instance be to what extent the OHS representatives get involved in practical problem-solving and whether the risk of moving away from colleagues does, in practice, materialize. Additionally, the possibilities for participation in more strategic decisions should be further explored.

\section{Declaration of Conflicting Interests}

The author(s) declared no potential conflicts of interest with respect to the research, authorship, and/or publication of this article.

\section{Funding}

This research was supported by the Danish Working Environment Fund.

\section{Note}

1. www.arbejdsmiljoforskning.dk/da/arbejdsmiljoedata/arbejdsmiljoe-og-helbred-20/arbejdsmiljoog-helbred-2012/sammenhaeng-mellem-arbejdspladsernes-svar-og-de-ansattessvar (accessed 11 March 2014)

\section{References}

Aalders M and Wilthagen T (1997) Moving beyond command-and-control: Reflexivity in the regulation of occupational safety and health and the environment. Law and Policy 19(4): 415443.

Aminoff S and Lindström KG (1981) Effektivare former för skyddsarbetet och skyddsarbetets organisation. Garpenberg: Skogshögskolan.

Andersen SK, Dølvik JE and Ibsen CL (2014) Nordic Labour Market Models in Open Markets. Brussels: European Trade Union Institute.

Baccaro $L$ and Howell C (2011) A common neoliberal trajectory: The transformation of industrial relations in advanced capitalism. Politics and Society 39(4): 521-563.

Blewett V and Dorrian J (2011) Partnering for OHS Final Report. Adelaide: University of South Australia.

Booth C and Bennett C (2002) Gender mainstreaming in the European Union: Towards a new conception and practice of equal opportunities? European Journal of Women's Studies 9(4): 430-446.

Broberg $\mathrm{O}$ and Hermund I (2004) The OHS consultant as a 'political reflective navigator' in technological change processes. International Journal of Industrial Ergonomics 33: 315-326.

Busck O (2014) Arbejdsmiljøet: hvorfor virker reguleringen ikke bedre? - Arbejdsmiljøregulering og indsats gennem 40 år. In: Jørgensen $\mathrm{H}$ (ed.) Arbejdsmarkedsregulering. Copenhagen: Jurist- og $\varnothing$ konomforbundet, pp. 241-285. 
Crouch C (2012) National varieties of labour market exposure. In: Morgan G and Whitley R (eds) Capitalisms and Capitalism in the Twenty-First Century. Oxford: Oxford University Press, pp. 90115.

Cutler T and James P (1997) Moving beyond the side-car syndrome: A case of self-interest? New Solutions 7(3): 46-52.

DA (2014) Arbejdsmarkedsrapport 2014. Copenhagen: Danish Confederation of Employers.

Dyreborg J (2011) 'Safety matters have become too important for management to leave it up to the workers': The Nordic OSH model between implicit and explicit frameworks. Nordic Journal of Working Life Studies 1(1): 135-160.

Elden M (1986) Sociotechnical systems ideas as public-policy in Norway: Empowering participation through worker-managed change. Journal of Applied Behavioral Science 22(3): 239-255.

European Agency for Safety and Health at Work EU-OSHA (2010) Mainstreaming OSH into business management. Working Environment Information. doi.org/10.2802/2138.

Frick K (1990) Can management control health and safety at work? Economic and Industrial Democracy 11(3): 375-399.

Frick K (2011) Worker influence on voluntary OHS management systems: A review of its ends and means. Safety Science 49(7): 974-987.

Frick K (2013) Resilience within a weaker work environment system: The position and influence of Swedish safety representatives. In: Nichols T and Walters D (eds) Safety or Profit? International Studies in Governance, Change and the Work Environment. Amityville, NY: Baywood Publishing, pp. $51-70$.

Frick K and Johanson U (2013) Systematiskt arbetsmiljö-syfte och inriktning, hinder och möjligheter verksamhetsstyrningen: En analys av svenska fallstudier. Rapport 2013:11. Stockholm: Arbetsmiljöverket.

Frick K , Jensen PL, Quinlan M and Wilthagen T (eds) (2000) Systematic Occupational Health and Safety Management: Perspectives on an International Development. Oxford: Pergamon.

Gallagher C, Rimmer M and Underhill E (2001) Occupational Health and Safety Management Systems: A Review of Their Effectiveness in Securing Healthy and Safe Workplaces. Sydney: National Occupational Health and Safety Commission.

Gallie D (2009) Institutional regimes and employee influence at work: A European comparison. Cambridge Journal of Regions, Economy and Society 2(3): 379-393.

García AM, López-Jacob MJ, Dudzinski l et al. (2007) Factors associated with the activities of safety representatives in Spanish workplaces. Journal of Epidemiology and Community Health 61(9): 784-790.

Gumbrell-McCormick R and Hyman R (2013) Trade Unions in Western Europe: Hard Times, Hard Choices. Oxford: Oxford University Press.

Gustavsen B (2007) Work organization and 'the Scandinavian Model'. Economic and Industrial Democracy 28(4): 650-671.

Hagen IM and Trygstad SC (2009) Local flexicurity: Resolving the conflict between direct and representative participation. Transfer: European Review of Labour and Research 15(3-4): 557577.

Hall A, Forrest A, Sears A and Carlan N (2006) Making a difference: Knowledge activism and worker representation in joint OHS committees. Relations Industrielles / Industrial Relations 61(3): 408436.

Harris LA, Olsen KB and Robyn JW (2012) Role typology for health and safety representatives.

Employee Relations 34(5): 481-500.

Hasle P (2001) Sikkerhedsorganisationens lange vej. Tidsskrift for Arbejdsliv 3(2): 95-110. 
Hasle P and Sørensen OH (2013) Employees as individually and collectively acting subjects: Key contributions from Nordic working life research. Nordic Journal of Working Life Studies 3(3): 930.

Hasle P and Zwetsloot GI (2011) Editorial: Occupational health and safety management systems: Issues and challenges. Safety Science 49(7): 961-963.

Hohnen P and Hasle P (2010) Arbejdsmiljøledelse, politiske processer og medarbejderinddragelse. In: Rocha RS and Hohnen P (eds) Ledelse af arbejdsmiljø - certificering i praksis. Copenhagen: Nyt Teknisk Forlag, pp. 78-97.

Hovden J, Lie T, Karlsen JE and Alteren B (2008) The safety representative under pressure: A study of occupational health and safety management in the Norwegian oil and gas industry. Safety Science 46(3): 493-509.

Jacobsen K (2011) Velfærdens pris: Arbejderbeskyttelse og arbejdsmiljø gennem 150 år. Copenhagen: Gad.

James P and Walters D (2002) Worker representation in health and safety: Options for regulatory reform. Industrial Relations Journal 33(2): 141-156.

Jensen PL (2002a) Assessing assessment: The Danish experience of worker participation in risk assessment. Economic and Industrial Democracy 23(2): 201-228.

Jensen PL (2002b) Human factors and ergonomics in the planning of production. International Journal of Industrial Ergonomics 29(3): 121-131.

Jørgensen H (2002) Consensus, Cooperation and Conflict: The Policy Making Process in Denmark. Cheltenham: Edward Elgar.

Kluge S (2000) Empirically grounded construction of types and typologies in qualitative social research. Forum Qualitative Sozialforschung / Forum: Qualitative Social Research 1(1). Available at: www.qualitative-research.net/index.php/fqs/article/view/1124.

Knudsen H, Busck O and Lind J (2011) Work environment quality: The role of workplace participation and democracy. Work, Employment and Society 25(3): 379-396.

Kristensen PH (2003) Et grænseløst arbejde. En fantastisk fortælling om danske tillidsvalgtes arbejde med at sikre arbejde, indflydelse og fremtid i multinationale selskaber. Copenhagen: Nyt fra Samfundsvidenskaberne.

Kristensen PH (2011) Managing OHS: A route to a new negotiating order in high-performance work organizations? Safety Science 49(7): 964-973.

Kristensen PH and Rocha RS (2012) New roles for the trade unions: Five lines of action for carving out a new governance regime. Politics and Society 40(3): 453-479.

Lorenz E and Lundvall BÅ (2011) Accounting for creativity in the European Union: A multi-level analysis of individual competence, labour market structure, and systems of education and training. Cambridge Journal of Economics 35(2): 269-294.

Mathiesen K and Hvenegaard H (2001) New work councils: Expanded cooperation in the public sector in Denmark. Human Factors and Ergonomics in Manufacturing 11(2): 145-157.

Navrbjerg S and Larsen TP (2015) Decentralising the Danish bargaining model: Changing the relations between shop stewards, management and unions. In: Industrial Relations in Europe Conference, Gothenburg, 10-11 September 2015.

Navrbjerg S, Larsen TP and Johansen MM (2010) Sikkerhedsrepræsentanten som organisationsrepræsentant. Copenhagen: Landsorganisationen i Danmark.

Neumann WP and Dul J (2010) Human factors: Spanning the gap between OM and HRM. International Journal of Operations and Production Management 30(9-10): 923-950.

Ollé-Espluga L, Menéndez-Fuster M, Muntaner C et al. (2014) Safety representatives' views on their interaction with workers in a context of unequal power relations: An exploratory qualitative study in Barcelona (Spain). American Journal of Industrial Medicine 57(3): 338-350. 
Rasmussen HB, Hasle P and Andersen PT (2014) Safety representatives' roles and dilemmas in the Danish oil and gas industry. Policy and Practice in Health and Safety 12(1): 17-34.

Rieper O (1985) Styring af arbejdsmiljøet - regel eller deltager - Et sociologisk studie af styringsmodeller på arbejdsmiljøområdet. København: Nyt Nordisk Forlag Arnold Busck.

Robens LA (1972) Report of the Committee of Inquiry into Safety and Health at Work. London: HMSO.

Robson LS, Clarke J, Cullen K et al. (2007) The effectiveness of occupational health and safety management systems: A systematic review. Safety Science 45(3): 329-353.

Rolfsen M (2011) How close can we dance? Labour-management partnership on a borderline. Economic and Industrial Democracy 32(4): 591-608.

Sjöström J (2013) Det komplexa deltagandet. Praktikgemenskaper, kunskapsprocesser och arbetsmiljöarbete vid ett pappersbruk. Linköping: Linköping Universitet.

Sørensen OH, Hasle P and Bach E (2007) Working in small enterprises - is there a special risk? Safety Science 45(10): 1044-1059.

Sørensen OH, Hasle P and Navrbjerg SE (2009) Local agreements as an instrument for improvement of management-employee collaboration on occupational health and safety. Economic and Industrial Democracy 30(4): 643-672.

Tasiran AC, Walters D, Nichols T et al. (2005) The Role and Effectiveness of Safety Representatives in Influencing Workplace Health and Safety. Research Report, 363. Sudbury: HSE Books.

Walby S (2005) Gender mainstreaming: Productive tensions in theory and practice. Social Politics: International Studies in Gender, State and Society 12(3): 321-343.

Walters D (1995) Employee representation and occupational health and safety: The significance of Europe. Journal of Loss Prevention in the Process Industries 8(6): 313-318.

Walters D (2002) Regulating Health and Safety Management in the European Union. Brussels: P.I.E.-Peter Lang.

Walters D and Frick K (2000) Worker participation and the management of occupational health and safety: Reinforcing or conflicting strategies. In: Frick K et al. (eds) Systematic Occupational Health and Safety Management. Oxford: Pergamon, pp. 42-65.

Walters D and Jensen PL (2000) The discourse and purposes behind the development of the EU framework directive 89/391. In: Frick K et al. (eds) Systematic Occupational Health and Safety Management. Oxford: Pergamon, pp. 87-99.

Walters D and Nichols T (2007) Worker Representation and Workplace Health and Safety. Basingstoke: Palgrave Macmillan.

Walters D and Nichols T (2009) Workplace Health And Safety: International Perspectives on Worker Representation. Basingstoke: Palgrave Macmillan.

Walters D, Wadsworth E, Marsh K et al. (2012) Worker Representation and Consultation on Health and Safety: An Analysis of the Findings of the European Survey of Enterprises on New and Emerging Risks (ESENER). Report. Bilbao: European Agency for Safety and Health.

Wilthagen T (1994) Reflexive rationality in the regulation of occupational safety and health. In: Rogowski R and Wilthagen T (eds) Reflexive Labour Law: Studies in Industrial Relations and Employments Regulation. Deventer: Kluwer Law and Taxation Publishers, pp. 345-376.

Yin RK (2009) Case Study Research: Design and Methods. London: Sage.

\section{Author biography}

Peter Hasle is professor at the Centre for Industrial Production, Aalborg University Copenhagen. His research interests are economic and social sustainable production with a focus on integration of productivity and the work environment. He has published in the fields of organizational social 
capital, occupational health and safety management, small enterprises and healthcare. His recent publications include 'Lean production: An evaluation of the possibilities for an employee supportive lean practice', Human Factors and Ergonomics in Manufacturing and Service Industry (2014) 24(1): 40-53.

Rikke Seim is associate professor at DTU Management Engineering, the Technical University of Denmark. Her research interests are management and design of work systems and workspace design with a focus on work environment and occupational health and safety. Previous research has focused on employee participation, interventions and human resource management. She has recently published, with O Broberg and V Andersen, 'Ergonomics in design processes: The journey from ergonomist toward workspace designer', Human Factors and Ergonomics in Manufacturing and Service Industries (2014) 24(6): 656-670.

Bjarke Refslund, PhD, is a researcher at the Centre for Industrial Production, Aalborg University Copenhagen. His main research interests are work organization and industrial relations as well as occupational health and safety and how these evolve when faced with changes in product and labour market composition. His current work includes a project on precarious employment and social dialogue. Recent publications include 'Intra-European labour migration and deteriorating employment relations in Danish cleaning and agriculture: Industrial relations under pressure from EU8/2 labour inflows?', Economic and Industrial Democracy (2014), and, with Ines Wagner, 'Understanding the diverging trajectories of slaughterhouse work in Denmark and Germany: A power resource approach', European Journal of Industrial Relations (2016). 